\title{
Trump's Speech about Jerusalem: An Analysis on Persuasive Strategies
}

\author{
Ahmad Faiz \\ Unipdu Jombang \\ Faizelf13@gmail.com \\ Andi Indah Yulianti \\ Balai Bahasa Sulawesi Selatan \\ andiindahyulianti@gmail.com \\ Dwiani Septiana \\ Balai Bahasa Kalimantan Tengah \\ dwianiseptiana22@gmail.com
}

DOI: https://doi.org/10.18326/jopr.v2i2.160-176

Copyright (C) The Author (s)

This work is licensed under a Creative Commons Attribution-ShareAlike 4.0 International License.

How to Cite: Faiz, A., Yulianti, A., \& Septiana, D. (2020). Trump's Speech about Jerusalem: An

Analysis on Persuasive Strategies. Journal of Pragmatics Research, 2(2), 160-177.

doi:https://doi.org/10.18326/jopr.v2i2.160-177




expressed pathos by showing his perceived intelligence, virtuous character and goodwill to create peace in Jerusalem. Logos were expressed while Trump showed factual information about the role of Israel in creating peace in Jerusalem. Trump mostly expressed pathos to affect hearers' emotion by creating mildness, giving admiration and confession. Therefore, in achieving the goals of his speech, Trump intended to persuade hearers by touching their emotion.

Key words: persuasive strategies, speech, Donald Trump

\section{INTRODUCTION}

Jerusalem is a holy place where several beliefs and faiths live together. Islam, Christianity and Jews live and do worship in that city (BBC, 2017). Its territory surrounds Palestine and Israel. Both countries have been being a great rivalry in an old-world war since 1948 (Margolick, 2008). Donald Trump as the president of USA showed his sympathy toward both a long-world war and it was stated through his political speech. Stobbs (2012) considered that political speeches are written with a very great plan and purpose. As the president of USA, Trump is the most influential person in the world. His word will always provoke great responses from all people over the world. He showed his remark on his speech about Jerusalem on $23^{\text {rd }}$ May 2017. Through his speech, he expected the three religions in Jerusalem, such as Jews, Islam and Christianity can build peace together. On $6^{\text {th }}$ December 2017, Trump declared Jerusalem as the capital city of Israel. It provoked pros and cons from several leaders of nations over the world. He stated that his claim was to stop the war between Israel and Palestine, and to achieve peace. Through his speech, Trump intended to show his power and communicate what he wanted to. Speech is one the ways of having communication (Soedjarwo, 2020). In having communication, the speaker influences hearer to believe in what he says or doing something that he wants to. Alfian, Santi, and Sari (2019) stated that a good communication depends on how speaker can achieve the goal of what he says. Speaker absolutely persuades hearers to achieve the goals of communication.

In Persuading hearers, speaker can uses persuasive strategies. Speaker uses persuasive strategies to influence other people through utterance without doing compulsion. Gass and Seiter (2010) stated that persuasion is an attempt to influence hearers motives and attitudes. 
Roberts (2008) stated that Aristotle divided persuasive strategies into three ethos, logos and pathos. Ethos occurs when the speaker persuades hearer by showing his credibility in doing something. Griffin (2012) and Lucas (2009) defined ethos as ethical proof which means the way the speaker stated his ability, intelligence, reputation and etc. through his utterance. In the book of Griffin (2012), ethos are divided into three characteristics, which means that the speaker might express ethos indicating perceived intelligence, virtuous character, and goodwill. Perceived intelligence occurs when speaker persuaded hearers by showing his or her intelligence or competence in doing something. Verderber, Sellnow, and Verderber (2012) stated that audiences are more effectively persuaded by the speaker by showing his or her intelligence or competence through stating his perceived intelligence. Virtuous Character occurs when speakers intends to persuade hearers by building their trustworthiness. It can be raised when the speaker shows his experiences, motives, and values. The speaker can state that his intention in achieving something and the positive side belongs to him to persuade hearers. In previous research, Widyawardhani (2016) analysing rhetoric on Trump's presidential candidacy speech also showed that Trump expressed his virtuous character by showing his good character to persuade audiences. Goodwill occurs when speaker shows his hope which also becomes hearers hope. Griffin (2012) stated that goodwill is when the speaker intended to create a positive judgment from hearers to him. Zakariya, Chojimah, and Nurhayani (2018) analysing rhetorical strategies on SBY and Jokowi's speech about the increase of fuel also found that Jokowi showed his goodwill by telling his hope to actualize people's dreams by giving some solutions to increase people's prosperity.

The second type of persuasive strategies is logos. It is expressed to give a logic reason in a speech. Griffin (2012) defined logos as a logical proof. It occurs when the speaker presents a logical aspect of the utterance. The logical aspect is in the form of evidence. By presenting evidence, the speaker intends to convince hearers that what he says is reasonable to be received. Ghazani (2016) stated that logos occurs when speaker gives rational evidence. The third level of persuasive strategies is Pathos. It is expressed when the speaker touches the emotional aspect of hearers through discourse. Griffin (2012) stated that pathos is an emotional proof, an interaction between the speaker and hearer through speech involving feeling. Emotional aspect is a very important way to get an effective result in influencing people. Pathos can be expressed 
by the speaker while showing anger, mildness, confidence, admiration, fear, confession, love or friendship, hatred, pity, and envy.

There are previous research analyzed persuasive strategies used by influential speakers. Setiawan (2014) analyzed persuasive strategies used by Obama on his victory speech in 2012. The result showed that Obama mostly used pathos rather than ethos and logos. It indicates that Obama persuaded hearers by arousing their emotion. Shabrina (2016) analyzed persuasive strategies used by Hillary Clinton. The result showed that Hillary Clinton used ethos to show her good image and used pronoun 'we' to take hearers as the same position with her. Pathos was used by Hillary Clinton to affect hearers emotion by driving herself as a part of them and logos was used to give logical and factual evidences. Nurrosyidah (2016) analyzed persuasive strategies used by Jokowi in his political speech. The result showed that Jokowi used ethos by telling his reputation, character and knowledge. Pathos was used to affect hearers emotion by using figurative language and logos was used by telling factual data, statistic and example. This research was also conducted to analyze the most influential person over the world, that is Donald Trump. Therefore, the aim of this research is to analyze the type of persuasive strategies used by Donald Trump on his speech about Jerusalem

\section{RESEARCH METHOD}

This research used qualitative approach to get a deeper understanding of a phenomenon. The analysis of qualitative research is in the form of word. Its approach is the appropriate method to analyze pragmatic research as to describe and interpret the meaning of a text. Miles and Huberman (1994) stated that qualitative research deals with the analysis of a social phenomenon through classifying, interpreting, contrasting and etc.

The data of this research is Trump's speech about Jerusalem. There are two speech analyzed in this research. The first one is Trump's speech about Jerusalem on $23^{\text {rd }}$ March 2017 with the title "Remarks by President Trump at Israel Museum" (2017). The second one is Trump's speech about Jerusalem on $6^{\text {th }}$ December 2017 with the title "Statement by President Trump on Jerusalem" (2017b). The full texts were obtained from www.WhiteHouse.com. This research used human instrument, that is the writers. Peredaryenko and Krauss (2013) stated that human instrument is the writer as the instrument in conducting all the process of the analysis of the research. The other instrument is the types of persuasive strategies. 
Table 1. Characteristics of Persuasive Strategies

\begin{tabular}{|c|}
\hline Types of Persuasive Strategies \\
\hline Ethos \\
\hline Logos \\
\hline Pathos \\
\hline
\end{tabular}

Based on table 1, the data is classified into three types of persuasive strategies, those are ethos, logos and pathos. The number of the data is based on the order of the full text of Trump's speech about Jerusalem from the first speech and then followed with the second speech. Due to the limit of the words, this research analyzed several data only. The data is analyzed and discussed to investigate the types of persuasive strategies used by Trump on his speech about Jerusalem.

\section{RESULTS \&DISCUSSION}

This research analyzed and discussed the findings of persuasive strategies used by Trump on speech I and speech II.

\section{Speech I}

This subchapter analyzed persuasive strategies act in speech I, with the title "Remarks by President Trump at the Israel Museum”.

Table 2. Findings of Persuasive Strategies on Speech I

\begin{tabular}{lll}
\hline No & $\begin{array}{l}\text { Types of Persuasive } \\
\text { Strategies }\end{array}$ & Total of Findings \\
\hline 1. & Ethos & 9 data \\
\hline 2. & Logos & 3 data \\
\hline 3. & Pathos & 22 data \\
\hline
\end{tabular}

Based on table 2, there are 34 findings of persuasive strategies that were expressed on speech I. The findings show there are three types of persuasive strategies were reflected, those are ethos (9 data), logos (3 data) and pathos (22 data). It shows that the findings of pathos were mostly expressed with 22 data found. 


\section{Ethos}

\section{Datum 4}

This trip is focused on that goal: bringing nations together around the goal of defeating the terrorism that threatens the world, and crushing the hateful ideology that drives it so hard and seems to be driving it so fast. It is a privilege to stand here in this national museum, in the ancient city of Jerusalem, to address the Israeli people and all people in the Middle East who yearn for security, prosperity and peace.

Datum 4 indicates ethos. The text is categorized as declarative sentence because the speaker gave a statement. Ethos was expressed because Trump persuaded hearers by showing his credibility. He convinced hearers that by telling the motives of his trip into several goals. By showing the motives, he intended to build hearers' trustworthiness. Therefore, ethos is categorized as virtuous character.

Datum 12

I make this promise to you: My administration will always stand with Israel.

Datum 12 indicates ethos. The text is categorized as declarative sentence because the speaker gave a statement. Ethos was expressed because Trump persuaded by showing his credibility in doing something. He promised that he will always support Israel. By promising, he intended to build hearers" trustworthiness toward his reign. Therefore, ethos expressed in datum 12 is categorized as virtuous character.

\section{Datum 14}

Today, gathered with friends, I call upon all people - Jews, Christians, Muslims, and every faith, every tribe, every creed - to draw inspiration from this ancient city, to set aside our sectarian differences, to overcome oppression and hatred, and to give all children the freedom and hope and dignity written into our souls.

Datum 14 indicates ethos. The text is categorized as imperative sentence because the speaker requested something. Ethos was expressed because Trump persuaded hearers by showing his credibility in doing something. He invited every tribe, faith, and creed to follow him in achieving several goals. It showed that he intended to say that by following him, their hopes would be achievable. Therefore, ethos is categorized as goodwill as Trump wanted to build positive judgment in achieving their hopes.

\section{Datum 18}

My message to that summit was the same message I have for you: We must build a coalition of partners who share the aim of stamping out 
extremist and violence, and providing our children a peaceful and hopeful future. But a hopeful future for children in the Middle East requires the world to fully recognize the vital role of the State of Israel. (Applause.) And, on behalf of the United States, we pledge to stand by you and defend our shared values so that together we can defeat terrorism and create safety for all of God's children. (Applause.)

Datum 18 indicates ethos. The text is categorized as imperative sentence because the speaker requested something to do. Ethos was expressed because Trump persuaded hearers by showing his credibility in doing something. Through the message stated, he asked all people to make a coalition to achieve several goals. He invited all people to join him to create peace by fighting against terrorism, violence, and extremist. In the last sentence, he stated "together we can defeat terrorism and create safety...". It showed that by joining him, the hope of creating peace would be reachable. Therefore, ethos is categorized as goodwill because Trump intended to create positive judgment from hearers to him.

Datum 22

My administration is committed to pursuing such a coalition, and we have already made substantial progress during this trip.

Datum 22 indicates ethos. The text is categorized as declarative sentence because the speaker gave a statement. Ethos was expressed because Trump persuaded hearers by showing his credibility in doing something. He promised that USA under his administration to make a coalition which has made substantial progress during the trip. By convincing hearers, he intended to create the positive side of his administration to build hearers' trustworthiness. Therefore, ethos is categorized virtuous character.

Datum 23

As I have repeatedly said, I am personally committed to helping Israelis and Palestinians achieve a peace agreement, and I had a meeting this morning with President Abbas and can tell you that the Palestinians are ready to reach for peace.

Datum 23 indicates ethos. The text is categorized is declarative sentence because the speaker gave a statement. Ethos was expressed because Trump persuaded hearers by showing his credibility in doing something. He promised that he would help Israel to achieve peace which can be achieved through having a meeting with President Abbas that morning. By stating "personally", he strengthened the consistency of his promise. It showed that He intended to 
show his positive side and motive in having a meeting with President Abbas to build hearers' trustworthiness. Therefore, ethos is categorized as virtuous character.

Datum 25

But even as we work toward peace, we will build strength to defend our nations.

Datum 25 indicates ethos. The text is categorized as declarative sentence. Ethos was expressed because Trump persuaded hearers by showing his credibility in doing something. He talked about his work on creating peace by showing the ability of his administration in building strength to defend the Nations. It showed that ethos is categorized as perceived intelligence because Trump explicitly talked about his competence in doing something.

Logos

Datum 15

Earlier this week, I spoke at a very historic summit in Saudi Arabia. I was hosted by King Salman - a very wise man. There, I urged our friends in the Muslim world to join us in creating stability, safety and security. And I was deeply encouraged by the desire of many leaders to join us in cooperation toward these shared and vital goals.

Datum 15 indicates logos. The text is categorized as declarative because the speaker gave a statement for telling information. Logos was expressed because Trump persuaded hearers by giving logical proof or evidence. He told hearers about what he said in his speech in Saudi Arabia. On his speech, he invited Muslims and many leaders to join him in reaching peace and several goals. In the first sentence, he showed the time signal by saying "earlier this week" to convince hearers that what he said was a true event. It showed that logos is categorized as example because Trump gave factual examples.

\section{Datum 19}

Israelis have experienced firsthand the hatred and terror of radical violence. Israelis are murdered by terrorist wielding knives and bombs. Hamas and Hezbollah launch rocket into Israeli communities where schoolchildren have to be trained to hear the sirens and run to the bomb shelters - with fear, but with speed. ISIS target Jewish neighborhoods, synagogues, and storefront. And Iran's leaders routinely call for Israel's destruction. Not with Donald J. Trump, believe me. (Applause.) Thank you. I like you too. (Laughter.)

Datum 19 indicates logos. The text is categorized as declarative sentence because the speaker gave statement for telling an information. Logos was expressed because Trump gave 
logical proof or evidence. He talked about the tragedy of several violences attacking Israelis from Hamas, Hezbollah, ISIS and Iran. In the last sentence, he convinced hearers that it would never happen under his administration. It showed that logos is categorized as example because Trump gave factual example.

\section{Datum 27}

Under my administration, you see the difference - big, big beautiful difference - (laughter and applause) — including the Iron Dome missile defense program, which has been keeping the Israeli people safe from short-range rocket launched by Hezbollah and Hamas, and David's Sling, which guards against long range missiles.

Datum 27 indicates logos. The text is categorized as declarative sentence because the speaker gave statement by telling information. Logos was expressed because Trump persuaded hearers by giving logical proof or evidence. He talked about the power of unity of America and Israel under his administration is stronger than ever. He told the fact of the big difference that his program has resulted effective impact such as Iron Dome missile defense program. $\mathrm{He}$ strengthened the difference of the power under his administration by stating "big, big beautiful difference". It showed that logos is categorized as example because Trump gave factual example.

\section{Pathos}

\section{Datum 2}

I'd like to begin my remarks today by sending the thought and prayers of the entire American people to the victims of the terrorist attack in Manchester. You know - you've all been watching. You've seen just a horrible thing going on. I want to send our condolences to the many families who lost their loved ones.

Datum 2 indicates pathos. The text is categorized declarative sentence because the speaker gave a statement. Pathos was expressed by Trump to persuade hearers by involving their emotions. He showed his sadness on the tragedy of the terrorist attack in Manchester. In the last sentence, he stated that he showed his condolences to the victims and their families. It showed that pathos was expressed by Trump to show his condolence.

Datum 11

Through your hardships, you have created one of the most abundant lands anywhere in the world - a land that is rich not only in history, culture, and opportunity, but especially in spirit. 
Datum 11 indicates pathos. The text is categorized as declarative sentence because the speaker gave a statement by telling his argument. Pathos was expressed because Trump persuaded hearers by involving emotion. Firstly, he praised Jewish people who have supported in building Jerusalem by recognizing it as the most abundant land in the world. And then, he praised Jerusalem as a land, rich of history, culture, and spirit. It showed that pathos is categorized as admiration.

\section{Datum 13}

In Israel, not only are Jews free to till the soil, teach their children, and pray to God in the ancient land of their fathers - and they love this land, and they love God — but Muslims, Christians, and people of all faiths are free to live and worship according to their conscience, and to follow their dreams, right here.

Datum 13 indicates pathos. The text is categorized as declarative sentence because the speaker gave a statement by telling his argument. Pathos was expressed because Trump persuaded hearers by involving their emotions. He claimed that Israel is not only for Jewish people but also for several faiths especially Muslims and Christians. It showed that pathos is categorized as confession.

Datum 16

Conflict cannot continue forever. The only question is when nations will decide that they have had enough — enough bloodshed, enough killing. That historic summit represent a new opportunity for people throughout the Middle East to overcome sectarian and religious divisions, to extinguish the fires of extremism, and to find common ground and shared responsibility in making the future of this region so much better than it is right now.

Datum 16 indicates pathos. The text is categorized as declarative sentence because the speaker gave a statement by telling his argument. Pathos was expressed because Trump persuaded hearers by involving their emotions. At the first sentence, he strengthened that conflict must be stopped. And then, he motivated people in Middle East to stop the conflict by doing several actions to create a better future. It showed that pathos is categorized as motivation.

Datum 17

Change must come from within. It can only come from within. No mother or father want their children to grow up in a world where terrorist roam free, schoolchildren are murdered, and their loved ones are taken. No child is born with prejudice in their heart. No one should teach 
Datum 17 indicates pathos. The text is categorized as declarative sentence because the speaker gave a statement by telling his argument. Pathos was expressed because Trump persuaded hearers by involving their emotions. At the first line, he motivated people that a change resulting peace must be started from people inside Jerusalem. He strengthened his motivation by repeating "come from within" twice. And then, he emphasized that no people want their children to grow up in a conflict. He even repeated the sentences started with "No" four times. It showed that pathos is categorized as motivation.

\section{Datum 32}

Today, in Jerusalem, we pray and we hope that children around the world will be able to live without fear, to dream without limit, and to prosper without violence.

Datum 32 indicates pathos. The text is categorized as imperative sentence as the speaker requested hearers to do something. Pathos was expressed because Trump persuaded hearers by involving their emotions. He invited people to pray and make hope for their children may have a better life. It showed that pathos is categorized as love.

\section{Speech II}

This subchapter analyzed persuasive strategies act in speech I, with the title "Statement by President Trump on Jerusalem”.

Table 3. Findings of Persuasive Strategies on Speech II

\begin{tabular}{llc}
\hline No & $\begin{array}{l}\text { Types of Persuasive } \\
\text { Strategies }\end{array}$ & Total of Findings \\
\hline 1. & Ethos & 9 \\
\hline 2. & Logos & 3 \\
\hline 3. & Pathos & 8 \\
\hline
\end{tabular}

Based on the table 3, there are 20 persuasive strategies were expressed on speech II. The findings show that there are three types were reflected, those are 
ethos (9 data), logos (3 data) and pathos (9 data). It shows that the findings of ethos were mostly reflected with 9 data found.

Ethos

Datum 36

My announcement today marks the beginning of a new approach to conflict between Israel and the Palestinians.

Trump expressed ethos in datum 36. The text is categorized as declarative sentence because the speaker gave a statement. It indicates ethos because Trump showed his competence through his actions. He convinced hearers that his announcement would be the start of his action in solving the conflict between Israel and Palestinians. Then, ethos in datum 36 is categorized as perceived intelligence.

Datum 38

Therefore, I have determined that it is time to officially recognize Jerusalem as the capital of Israel. While previous president have made this a major campaign promise, they failed to deliver. Today, I am delivering.

Datum 38 indicates ethos. The text is categorized as declarative sentence because the speaker gave a statement. Ethos was expressed because Trump stated the goodwill. At the second sentence, he stated the promise of previous president which has not been achieved yet. Then, he strengthened his statement by saying "Today, I am delivering" at the last sentence. It showed that he would like to achieve the hope of previous president as what all people expect that was to officially recognize Jerusalem as the capital of Israel.

Datum 39

I've judged this course of action to be in the best interest of the United States of America and the pursuit of peace between Israel and the Palestinians.

Datum 39 indicates ethos. The text is categorized as declarative sentence because the speaker gave a statement. Ethos reflected because Trump told the motive of his action. He stated that his action is the best interest in creating peace between Israel and Palestinians. By strengthening that his action is the best interest, he would like to build hearers' trustworthiness. Therefore, ethos is categorized as virtuous character.

\section{Datum 43}

That is why, consistent with the Jerusalem Embassy Act, I am also directing the State Department to begin preparation to move the American 
embassy from Tel Aviv to Jerusalem. This will immediately begin the process of hiring architect, engineers, and planners so that a new embassy, when completed, will be a magnificent tribute to peace.

Datum 43 indicates ethos. The text is categorized declarative sentence because the speaker gave a statement. It indicates ethos because Trump told his motive. He e would like to show his consistency in with Jerusalem Embassy Act to move the American embassy from Tel Aviv to Jerusalem. By showing his consistency, he intended to build hearers' trustworthiness. At the last sentence, he also convinced hearers his action will begin the process of some actions. Therefore, ethos is categorized as virtuous character.

\section{Datum 45}

The United States remains deeply committed to helping facilitate a peace agreement that is acceptable to both sides. I intend to do everything in my power to help forge such an agreement.

Datum 45 indicates ethos. The text is categorized as declarative sentence because the speaker gave a statement. Ethos was reflected because Trump wanted to build hearers' trustworthiness. He showed his purpose that United States promised to create peace and he would do used his power to reach it. Therefore, ethos is categorized as virtuous character.

\section{Logos}

\section{Datum 37}

Yet for over 20 years, every previous American president has exercised the law's waiver, refusing to move the US embassy to Jerusalem or to recognize Jerusalem as Israel's capital city

Datum 3 indicates logos. The text is categorized as declarative sentence because the speaker gave a statement. Logos was expressed because Trump told evidence to persuade hearers. He told the failure of the previous president in recognizing Jerusalem as Israel's capital city. By stating the year "20 years", he intended to strengthen that the event was a truth. It showed that he gave a factual example. Therefore, logos is categorized as giving example.

\section{Datum 41}

It was 22 years ago that the United States under President Truman recognized the state of Israel. Ever since then, Israel has made it capital in the city of Jerusalem, the capital the Jewish people established in ancient times. 
Datum 41 indicates logos. The text is categorized as declarative sentence because the speaker gave a statement. Logos was expressed because Trump told the historical event when President Truman recognized the state of Israel. He also told that Israel has made Jerusalem as its capital city, as Jewish people have established. By stating the time signal "22 years ago", he intended to convince hearers that what he said was the true event. It showed he told the factual example. Therefore, logos is categorized as giving example.

\section{Pathos}

\section{Datum 40}

Israel is a sovereign nation with the right, like every other sovereign nation, to determine it own capital. Acknowledging this as a fact is a necessary condition for achieving peace.

Datum 40 indicates pathos. The text is categorized as declarative sentence because the speaker gave a statement. Pathos was expressed because Trump involved hearers' emotions. He stated that Israel is a sovereign city which has the right like other countries to choose their own capital. By saying it, he intended to show his confession on Israel. He strengthened that Israel has the right choose Jerusalem as their capital city. Then, pathos is categorized as confession.

\section{Datum 46}

Without question, Jerusalem is one of the most sensitive issues in those talks.

Datum 46 indicates pathos. The text is categorized as declarative sentence is the speaker gave a statement. Pathos was expressed because Trump persuaded hearers by involving their emotional aspect. He stated that Jerusalem is one of the most sensitive issues. By stating "sensitive issues", he wanted to invite all people to focus on the conflict in Jerusalem. He intended to calm down the situation to face the high tension in Jerusalem. Therefore, pathos was expressed by Trump to create mildness.

\section{Datum 50}

This sacred city should call forth the best in humanity — lifting our sight to what is possible, not pulling us back and down to the old fight that have become so totally predictable.

Datum 50 indicates pathos. The text is categorized is declarative sentence because the speaker gave a statement. Pathos was expressed because Trump persuaded hearers by involving their emotions. He praised Jerusalem by stating "sacred city" and "the best in humanity". By 
stating "sacred city", he implicitly says that Jerusalem is a historical place. And by stating "the best in humanity", he implicitly said that Jerusalem is a place which needs to be realized for peace as the portrait of humanity. By praising Jerusalem, pathos was expressed by Trump to show his admiration toward Jerusalem.

\section{Datum 51}

I repeat the message I delivered at the historic and extraordinary summit in Saudi Arabia earlier this year: The Middle East is a region rich with culture, spirit, and history. It people are brilliant, proud, and diverse, vibrant and strong.

Datum 51 indicates pathos. The text is categorized as declarative sentence because the speaker gave a statement. Pathos was expressed because Trump persuaded hearers by involving their emotions. He praised Middle East by stating "The Middle East is a region rich with culture, spirit, and history". And, in the following sentence, he praised the people of Middle East. Therefore, pathos was expressed by Trump to show his admiration.

\section{Datum 52}

It is time for the many who desire peace to expel the extremist from their midst. It is time for all civilized nations, and people, to respond to disagreement with reasoned debate, not violence. And it is time for young and moderate voices all across the Middle East to claim for themselves a bright and beautiful future.

Datum 52 indicates pathos. The text is categorized as declarative sentence. Pathos was expressed because Trump persuaded hearers by involving their emotions. He convinced hearers that his action would successfully achieve all people's dreams. He strengthened it by stating "it is time.." for three times. In the last sentence, he stated that the time has come to claim a bright and beautiful future for all parts of Middle East. It showed that pathos was expressed by Trump to show his confidence on his action.

Based on the findings, there are 24 persuasive strategies in speech I and 20 persuasive strategies in speech II. All types of persuasive strategies were expressed by Trump on his speech about Jerusalem. Trump expressed ethos to show perceived intelligence, virtuous character and goodwill to create peace in Jerusalem. Logos were expressed while speaker intended to give factual information or logical proof by telling the role of Israel in creating peace in Jerusalem. 
And the last one is pathos that were expressed while Trump involve hearers emotion by creating mildness, giving admiration and confession.

\section{CONCLUSION}

Persuasive strategies are expressed by speaker to achieve the purpose with doing any actions. Trump used persuasive strategies to persuade hearers on his speech about Jerusalem. Trump expressed all types of persuasive strategies; those are ethos, logos and pathos. On his speech about Jerusalem, he mostly expressed pathos. It shows that Trump intended to achieve the purpose of his speech by showing his credibility in doing something, giving factual information and involving hearer's emotion. The next researcher can do research of pragmatic by analysing persuasive strategies on some influential persons over the world

\section{REFERENCES}

Alfian, Santi, C. F., \& Sari, N. (2019). Persuasive strategies used by Dr. Zakir Naik in his speech in Oxford Union with theme "Islam and 21st century. English Language, Linguistics, Literature and Educational Journal, 1(1), 32-44.

BBC. (2017, December 7). Yerusalem: Tiga hal yang perlu Anda ketahui tentang kota suci. BBC Indonesia. Retrieved from https://www.bbc.com/indonesia/majalah-42261448

Gass, R. H., \& Seiter, J. S. (2010). Persuasion, Social Influence, and Compliance Gaining (4th ed.). Boston: Allyn \& Bacon.

Ghazani, A. Z. (2016). Study of Persuasive Strategies in Selected American Presidential Speeches. International Journal of Humanities and Cultural Studies, 3(2), 631-647. Retrieved from https://www.ijhcs.com/index.php/ijhcs/article/view/2499/2546 Griffin, E. A. (2012). A first look at communication theory. New York: McGraw-Hill.

Lucas, S. E. (2009). The Art of Public Speaking (10th ed.). New York: McGraw-Hill.

Margolick, D. (2008). Endless War. New York Times. Retrieved from https://www.nytimes.com/2008/05/04/books/review/Margolick-t.html

Miles, M. B., \& Huberman, M. A. (1994). Qualitative Data Analysis. United States of America: Sage Publications.

Nurrosyidah, H. Y. (2016). Persuasive strategies in Joko Widodo's political speeches 
(Undergraduate Thesis). Universitas Islam Negeri Maulana Malik Ibrahim, Malang.

Peredaryenko, M. S., \& Krauss, S. E. (2013). Calibrating the Human Instrument: Understanding the Interviewing Experience of Novice Qualitative Researchers. The Qualitative Report, 18(43), 1-17. Retrieved from https://nsuworks.nova.edu/tqr/vol18/iss43/1/

Roberts, W. R. (2008). The Art Rethoric. Megaphone ebooks. Retrieved from http://www.wendelberger.com/downloads/Aristotle_Rhetoric.pdf

Setiawan. (2014). Persuasive strategies on Barrack Obama's victory speech in 2012 (Undergraduate Thesis). Sanata Dharma University Yogyakarta.

Shabrina, I. (2016). Persuasive strategies used in Hillary Clinton's political campaign speech (Undergraduate Thesis). Universitas Islam Negeri Maulana Malik Ibrahim, Malang.

Soedjarwo, G. N. (2020). Persuasion Act in the Proposal Movie. Journal of Pragmatics Research, 2(1), 50-67. https://doi.org/https://doi.org/10.18326/jopr.v2i1.50-67

Stobbs, J. G. (2012). Critical Discourse Analysis of Barack Obama's 1st Inaugural Speech. Retrieved from https://www.researchgate.net/publication/234058394_Critical_Discourse_Analysis_of_ Barack_Obama's_First_Inaugural_Speech

Verderber, R. F., Sellnow, D. D., \& Verderber, K. S. (2012). The Challenge of Eff ective Speaking (15th ed.). Boston: Wadsworth.

WhiteHouse. (2017a). Remarks by President Trump at the Israel Museum. Retrieved September 20, 2020, from https://www.whitehouse.gov/briefings-statements/remarks-presidenttrump-israel-museum/

WhiteHouse. (2017b). Statement by President Trump on Jerusalem. Retrieved September 20, 2020, from https://www.whitehouse.gov/briefings-statements/statement-presidenttrump-jerusalem/

Widyawardhani, Y. I. (2016). Rethorical Analysis of Donald Trump's Presidential Candidacy Announcement Speech (Undergraduate Thesis). Sanata Dharma University Yogyakarta. Zakariya, M. R., Chojimah, N., \& Nurhayani, I. (2018). Rhetoric and Discourse in Political Speeches. Alphabet, $1(2)$, 95-102. https://doi.org/https://doi.org/10.21776/ub.alphabet.2018.01.02.02 